\title{
PERGESERAN BAHASA DAERAH PADA ANAK-ANAK DI KUALA TANJUNG SUMATRA UTARA
}

\author{
Lokal Language Shifting on Children in Kuala Tanjung North Sumatra
}

\author{
Sahril \\ Balai Bahasa Sumatera Utara \\ oksahrilmelayu@ymail.com
}

Naskah Diterima Tanggal 14 Desember 2017—Direvisi Akhir Tanggal 20 November 2018—Disetujui Tanggal 1 Desember 2018 Doi https://doi.org/10.26499/rnh.v7i2.571

\begin{abstract}
Abstrak
Penelitian ini bertujuan untuk menggambarkan kondisi pergeseran bahasa daerah di kalangan anak-anak di wilayah Kuala Tanjung. Lebih lanjut, akan dilihat apakah faktor sikap dan peran orang tua memengaruhi penggunaan bahasa daerah. Untuk menjawab permasalahan tersebut, peneliti menggunakan populasi masyarakat Kuala Tanjung yang berdomisili di Kecamatan Sei Suka, Kecamatan Medang Deras, dan Kecamatan Air Putih, Kabupaten Batu Bara, Provinsi Sumatra Utara. Dari sejumlah populasi tersebut, diambil sampel sebanyak 20 anak-anak dan 20 orang tua dari tiap-tiap kecamatan. Jumlah sampel adalah 60 orang usia 6-12 tahun (usia pendidikan dasar) dan 60 orang tua (30-50 tahun, menikah), total sampel adalah 120 orang. Penelitian ini menggunakan metode deskriptif kuantitatif-kualitatif. Teknik pengumpulan data yang digunakan adalah observasi, kuesioner, dan wawancara yang dilengkapi dengan instrumen penelitian, yaitu pencatatan dan perekaman. Hasil penelitian menunjukkan adanya kondisi pergeseran bahasa di kalangan anak-anak di Kuala Tanjung berdasarkan analisis persentase data kuesioner. Penggunaan bahasa pada ranah keluarga dan ranah resmi dan tidak resmi di sekolah menunjukkan dominannya penggunaan bahasa Indonesia. Berdasarkan perhitungan persentase, hampir semua jawaban responden menunjukkan kurangnya penggunaan bahasa daerah oleh anak-anak walaupun dari segi sikap responden terhadap penggunaan bahasa daerah cukup mengembirakan, yang ditunjukkan oleh hasil persentase kuesioner. Akan tetapi, tidak memberi pengaruh pada pemertahanan bahasa daerah sehingga disimpulkan telah terjadi pergeseran bahasa.
\end{abstract}

Kata-kata kunci: sikap, peran orang tua, pergeseran bahasa

\begin{abstract}
This research aims to describe the condition of regional language shift among children in Kuala Tanjung. Afterwards, it will be studied whether the attitude factor and the parents' role affect the use of regional language. To answer this issue, the researcher involved the societies of Kuala Tanjung who live in the districts of Sei Suka, Medang Deras and Air Putih in Batu Bara Regency, North Sumatra Province. From these populations, samples are taken as many as 20 children from each district. The total sample is 60 people aged 6-12 years (primary education age), 60 parents (30-50 years, married), so the total sample is 120 people. This research used quantitative-qualitative descriptive method. Data collection techniques are observation, questionnaires and interviews through note taking and recording as the research instruments. The result of the research shows the condition of language shift among children in
\end{abstract}


Kuala Tanjung based on percentage analysis of questionnaire data. The use of language in the realm of family and official and unofficial domains in schools shows the dominance of Indonesian language usage. Based on the percentage calculations, almost all respondents' answers indicate a lack of regional language usage by children, although in terms of attitudes, the respondents' attitude towards regional language usage is quite encouraging, shown by the percentage of questionnaires. However, it does not affect the regional languages defense so that it is concluded that there has been a shift in language.

Keywords: attitude, parents' roles, language shift

How to Cite: Sahril. (2018). Pergeseran Bahasa Daerah pada Anak-Anak di Kuala Tanjung Sumatera Utara, Ranah: Jurnal Kajian Bahasa, 7 (2), 210-228. doi: https://doi.org/10.26499/rnh.v7i2.571

\section{PENDAHULUAN}

Sebagai masyarakat Indonesia yang sangat menghargai kekayaan budaya dan menjunjung tinggi martabat bangsa, seyogianya memelihara bahasa dan budaya sebagai warisan nenek moyang kepada generasi muda. Fenomena yang terjadi sekarang ini adalah anak-anak sangat jarang yang menggunakan bahasa daerah sebagai bahasa ibunya. Kondisi ini sangat memprihatinkan, para orang tua tidak lagi menekankan penggunaan bahasa daerah di lingkungan keluarga, mereka lebih bangga bila anak-anak hanya menggunakan bahasa Indonesia di rumah. Jika kondisi ini terus berlanjut, tidak menutup kemungkinan bahasa daerah pada akhirnya akan mengalami pergeseran, bahkan akan menjadi bahasa yang punah sebagaimana yang sudah terjadi pada beberapa bahasa daerah lainnya yang ada di Indonesia.

Tanggung jawab masyarakat untuk memelihara dan mempertahankan bahasa daerah sangat dibutuhkan demi menjaga kekayaan bangsa Indonesia. Para pengambil kebijakan dan institusi terkait hendaknya memberikan perhatian terhadap masalah yang dihadapi dan memberikan solusi yang tepat agar kepunahan bahasa dapat dihindari sebisa mungkin. Tentu saja dibutuhkan kerja sama antara pemerintah dan masyarakat untuk melakukan usaha-usaha yang berkenaan dengan pemertahanan bahasa daerah, khususnya dan pelestarian budaya pada umumnya. Usaha pemertahanan bahasa dapat dimulai dari lingkup yang lebih kecil, yaitu membiasakan penggunaan bahasa daerah dalam lingkungan keluarga, terutama pada anak-anak. Di sinilah peran orang tua dalam memperkenalkan bahasa daerah pada anak-anak dan membiasakan mereka untuk menggunakan dalam berinteraksi dengan anggota keluarga.

Seperti yang dikemukakan oleh Kramsch (1998) bahwa 'identitas' pada dasarnya menjadi alasan utama mengapa orang cenderung tetap menggunakan bahasa 
daerahnya. Tujuan mereka terutama untuk memperkenalkan siapa dirinya, sebagai individu atau kelompok sosial. Studi yang membahas tentang pengaruh identitas diri terhadap pemertahanan bahasa masih sangat terbatas dilakukan oleh ahli bahasa. Akan tetapi, penelitian yang berkenaan dengan topik ini sudah pernah dilakukan meskipun dalam jumlah yang masih terbatas.

Penelitian tentang pemertahanan bahasa sekarang ini telah banyak dilakukan di berbagai tempat, di mana terdapat masyarakat tertentu yang menuturkan bahasa daerahnya sebagai bahasa minoritas. Di antaranya, Adisaputera (2009), Jumharia (2015), Berutu (2016), Sembiring (2015), dan Rina (2017).

Dari beberapa penelitian terdahulu belum ditemukan ada yang meneliti pergeseran bahasa daerah di wilayah Kuala Tanjung. Selanjutnya, penelitian pergeseran bahasa untuk tingkat global yang dapat dijadikan acuan dalam penelitian ini, di antaranya ialah Moriguchi-McCormick (1999) yang meneliti hubungan antara sikap terhadap pemertahanan dan keaksaraan bahasa pertama di kalangan anak-anak Jepang. Chang (1996) meneliti penggunaan bahasa dan sikap bahasa di kalangan siswa Sekolah Dasar di Taiwan. Tse (2001) meneliti pengalaman dari satu kelompok bumbui asli AS yang telah berhasil mengembangkan tingkat melek huruf yang tinggi dalam bahasa Inggris dan bahasa rumah atau bahasa "warisan" mereka. Yagmur, Bot, \& Korzilius (1999) meneliti hubungan antara faktor masyarakat dan persepsi individu tentang situasi kontak bahasa sebagaimana tercermin dalam perilaku berbicara mereka.

Fishman (1980) merumuskan bahwa sebagian besar pendidikan dwibahasa tanpa sadar mengarah pada akomodasi transisi daripada akomodasi yang stabil di bidang bahasa dan budaya. Fishman (1990) membuat studi tentang perawatan bahasa dan pergeseran bahasa (RLS). Fishman \& Others (1966) mengenai upaya pemeliharaan bahasa dan prestasi para imigran berbahasa non-Inggris di Amerika.

Sementara dalam berbagai jurnal dan prosiding sepuluh tahun terakhir yang mengkaji mengenai pergeseran bahasa di tingkat global cukup banyak, itu menandakan bahwa masalah pergeseran bahasa memang menjadi satu masalah yang serius. Beberapa penelitian itu di antaranya, Fishman (2012), Hickey (2010), Gafaranga (2010), Hornberger \& King (2011), Kandler, Unger, \& Steele (2010), Küün (2015), MyersScotton (2013), Musgrave (2014), Posel \& Jochen (2016), Smith-Christmas (2014), Ozerk \& Jon (2013), dan Prochazka \& Gero (2017). 
Fenomena pemertahanan bahasa biasanya terjadi di daerah atau negara yang sering didatangi oleh transmigran atau imigran yang ingin memulai hidup baru di tempat yang baru. Tentu saja, ketika suatu etnik yang pindah ke daerah yang baru, mereka akan menjadi kelompok minoritas di tempat tersebut. Secara normal mereka dapat beradaptasi dengan kebiasaan masyarakat setempat agar mereka dapat diterima menjadi bagian dari penduduk asli tersebut. Jika mereka dapat hidup berdampingan dengan penduduk asli, tidak dapat dipungkiri bahwa mereka secara tidak sadar akan mengadopsi bahasa yang dituturkan oleh penduduk lokal. Akibatnya, mereka akan menjadi bilingual. Di satu sisi mereka tetap menuturkan bahasa ibunya dan di sisi lain mereka juga menuturkan bahasa lokal sebagai bahasa yang baru. Misalnya pada anakanak di Kuala Tanjung, karena daerah ini merupakan kawasan industri, jumlah pendatang cukup signifikan. Dalam berkomunikasi anak-anak ini menggunakan dua bahasa, yaitu bahasa ibunya dan bahasa lokal setempat saat berkomunikasi dengan anak-anak teman sepermainan yang berasal dari masyarakat setempat. Kondisi ini tidak dapat dielakkan sebagai pengaruh dari migrasi sehingga akulturasi dua bahasa akan terjadi.

Banyak faktor yang memengaruhi pergeseran bahasa daerah di Kuala Tanjung. Misalnya, jika dilihat dari kondisi demografi, penduduk Kuala Tanjung yang heterogen di mana terdapat banyak suku yang bermukim di sana, baik itu sebagai penduduk permanen maupun penduduk yang hanya menetap selama jangka waktu tertentu karena berbagai alasan, misalnya pindah tugas (karyawan) dan perniagaan. Adapun suku-suku daerah yang bermukim di Kuala Tanjung adalah masyarakat asli sekitar Kuala Tanjung, yaitu suku Melayu, Jawa, Batak, dan Tionghoa.

Kondisi inilah yang menyebabkan masyarakat di Kuala Tanjung lebih banyak menggunakan bahasa Indonesia sebagai alat komunikasi dengan berbagai suku yang ada sehingga mereka jarang lagi menggunakan bahasa daerah sebagai bahasa pengantar dalam berinteraksi sesama masyarakat Kuala Tanjung, terutama di kalangan anak-anak dan remaja. Bahasa daerah hanya dipakai oleh mereka yang dikategorikan kelompok usia dewasa dan lanjut usia, itu pun penggunaannya terbatas di lingkungan keluarga saja. Kondisi ini sangat memprihantikan. Anak-anak Kuala Tanjung tidak memahami, bahkan tidak lagi menuturkan bahasa ibu mereka. Penggunaan bahasa ibu dalam ranah 
keluarga akan membantu mereka untuk terus menggunakan bahasa daerah dari generasi ke generasi.

Penelitian ini akan difokuskan pada hubungan antara faktor sikap bahasa dan penggunaan bahasa daerah sebagai faktor yang memengaruhi pergeseran bahasa yang sedang terjadi di antara masyarakat penutur bahasa daerah. Sikap bahasa menyangkut bagaimana cara pandang terhadap penggunaan bahasa daerah dalam berbagai ranah sehingga sikap tersebut bisa positif atau negatif. Di samping itu, penelitian ini juga ingin menunjukkan bagaimana peran orang tua dalam membantu anak-anak menggunakan bahasa daerah dalam ranah keluarga. Frekuensi penggunaan bahasa yang tinggi dapat menyebabkan tingkat kebiasaan penggunaan bahasa tersebut dengan sadar.

\section{LANDASAN TEORI}

Bahasa merupakan milik perorangan dan sosial. Jika bahasa dituturkan secara perorangan, orang tersebut berperilaku secara individu seperti individu lainnya. Mereka dapat menuturkan bahasa, dialek, atau ragam bahasa yang sama, yaitu menggunakan kode yang sama, dan berhubungan dengan kelompok masyarakar tutur yang sama. Bahasa merupakan milik sosial dalam studi ilmu sosiolinguistik. Artinya, studi tentang penggunaan bahasa di antara kelompok tutur. “Kelompok” merupakan konsep yang sulit untuk dijelaskan, tetapi harus dipahami. Orang dapat membentuk kelompok berdasarkan satu atau lebih alasan, yaitu alasan sosial, agama, politik, budaya, keluarga, dan pekerjaan. Kelompok bisa bersifat temporer atau semi temporer dan tujuan anggotanya dapat diubah (Wardaugh, 2002).

Bentuk kelompok sosiolinguistik secara umum telah mencoba mempelajari studi yang disebut masyarakat tutur. Lyons (1970) dalam Wardaugh (2002) menawarkan definisi yang disebut masyarakat tutur yang "sebenarnya"; semua orang yang menggunakan bahasa (atau dialek). Kemudian, hal itu mengubah dari isu menjadi membuat definisi tentang bahasa (dialek) juga sekaligus definisi tentang bahasa masyarakat tutur.

Apa yang diuraikan sebelumnya menyampaikan secara tidak langsung bahwa bahasa akan dituturkan dengan berbeda berdasarkan kategori sosial. Oleh karena itu, organisasi sosial akan mengelompokkan ragam bahasa yang mereka tuturkan. Meskipun ada perbedaan dalam istilah sebagai masyarakat tutur dan pembuat tutur, pada dasarnya 
mereka memiliki tujuan yang sama, mereka membahas tentang bahasa yang digunakan dalam masyarakat di mana mereka dapat dikelompokkan dalam beberapa kelompok, seperti usia, jenis kelamin, pendidikan, kelas sosial, dan politik.

Kecenderungan masyarakat tutur ketika berinteraksi dengan yang lainnya adalah menuturkan bahasa yang dapat dimengerti satu sama lain atau dengan kata lain bahasa memiliki kejelasan (intelligibility) untuk membuat mereka menjadi bagian dari komunitas tersebut. Hal itu juga membuat mereka tidak bisa menuturkan hanya satu bahasa saja tanpa mengetahui bahasa lainnya. Jika seseorang tidak pernah meninggalkan daerah asalnya, hal ini menyebabkan mereka hanya mengetahui satu bahasa saja, yaitu bahasa daerahnya. Dia tidak akan tahu bahasa lain kecuali bahasanya sendiri. Masyarakat seperti itu disebut masyarakat tertutup yang tidak pernah membangun kontak dengan masyarakat tutur lainnya. Biasanya ini disebabkan daerah yang sangat terisolasi atau memang tidak ingin berkomunikasi dengan masyarakat lainya. Oleh karena itu, bentuk masyarakat seperti ini dikenal sebagai masyarakat tutur statis yang akan tetap menjaga kondisi sebagai masyarakat monolingual.

Akan tetapi, masyarakat yang hanya menuturkan satu bahasa jarang ditemukan sekarang ini, sedikitnya mereka mengetahui dua bahasa meskipun tidak menguasai bahasa kedua sebaik bahasa pertamanya. Sebaliknya, masyarakat tutur terbuka akan membangun hubungan dengan masyarakat lainnya, mereka akan mengalami kontak bahasa serta semua fenomena bahasa yang ada. Ada beberapa fenomena bahasa yang terjadi sebagai akibat dari kontak bahasa, seperti diglosia, campur kode, alih kode, interferensi, integrasi, konvergensi, dan pemertahanan bahasa (Chaer \& Leonie Agustina, 2004).

Sebagaimana masyarakat terbuka yang dapat berinteraksi dengan masyarakat lainnya, mereka akan tahu bahasa lain selain bahasa ibunya. Jika seorang dapat menguasai dua bahasa, dia akan dikenali sebagai bilingualisme. Istilah bilingualisme masih menjadi debat di antara para ahli linguistik kaitannya dengan penguasaan dua bahasa jika dikaitkan dengan bilingual. Ahli linguistik berpendapat bahwa orang yang dikategorikan sebagai bilingual jika dia menguasai dua bahasa, meskipun dia tidak menguasai bahasa kedua sebaik bahasa pertamanya. Ada juga ahli yang berpendapat bahwa seperti apa pun kemampuan kedua bahasa yang dimiliki, tidak perlu memiliki 
penguasaan yang sama pada kedua bahasa, orang tersebut sudah bisa dikatakan bilingual.

Jika membahas pergeseran bahasa, secara otomatis berhubungan dengan pemertahanan bahasa dan kepunahan bahasa. Fenomena bahasa ini adalah kumpulan pengaruh dari adanya pilihan bahasa. Pergeseran bahasa semata-mata berarti penggunaan bahasa yang sangat terbatas, baik dari segi penutur maupun tempat di mana bahasa itu dituturkan. Sebaliknya, pemertahanan bahasa adalah jika bahasa tersebut tetap digunakan meskipun dalam kondisi sebagai bahasa minoritas yang jumlah penuturnya tidak banyak karena dituturkan di antara bahasa yang mayoritas. Kepunahan bahasa akan terjadi jika bahasa tesebut tidak ada lagi penuturnya dan posisinya diganti oleh bahasa yang sebagian besar dituturkan oleh masyarakat yang mayoritas.

Pernyataan tersebut didukung oleh Fasold (1984) yang menyatakan bahwa "When a speech community begins to choose a new language in domains formerly reserved for the old one, it may be a sign that language shift is in progress. If the member of a speech community are monolingual and are collectively acquiring another language, then they are obviously maintaining their language-use-pattern. Maintenance, however, is often a characteristic of bilingual or multilingual communities as well. This only happens when the community is diglossic. Another way of saying the same thing is that language-maintaining multilingual communities reserve each language for certain domains with very little encroachment of one language on the domains of the others."

Pada kenyataannya, istilah 'maintenance' dan 'shift' diajukan dalam artikel yang pertama kali ditulis oleh Fishman (1964). Pemertahanan bahasa berarti penggunaan bahasa yang berkelanjutan dalam menghadapi persaingan dengan bahasa yang lebih banyak memiliki kekuatan secara sosial dan regional. Sebaliknya, pergeseran bahasa berarti pergantian satu bahasa oleh bahasa lainnya sebagai bahasa utama dalam berkomunikasi dan sosialisasi dalam masyarakat. Adapun istilah kepunahan bahasa digunakan jika komunitas pengguna bahasa itu tinggal satu, bahkan tidak ada lagi. Penelitian gejala bahasa tersebut telah lama dilakukan oleh Fishman \& Others (1966) dan Kloss (1966) yang memberikan solusi dan upaya-upaya untuk pemertahanan bahasa. Dua studi klasik tentang pergeseran bahasa dilakukan oleh Dorian (1981) dan Gal (1979) pada bahasa Gael di Skotlandia Timur bagian laut yang bergeser dari bahasa 
Hongaria ke bahasa Jerman pada komunitas Oberwart, Austria. Hingga sekarang, banyak studi yang fokus pada isu-isu bahasa tersebut sebagai lingkup sosiolinguistik makro (Mesthrie, 2000).

Ada beberapa faktor yang dapat memengaruhi bahasa dapat dipertahankan oleh penuturnya. Faktor-faktor tersebut juga menjadi alasan mengapa bahasa dapat bergeser atau sebaliknya dapat dipelihara. Faktor yang paling jelas yang dapat memengaruhi pergeseran bahasa adalah sikap penutur terhadap bahasa daerahnya sendiri. Hal ini dibuktikan oleh berbagai studi yang mengkaji bagaimana sikap dapat memengaruhi penggunaan bahasa daerah secara berkelanjutan dari generasi ke generasi. Pada umumnya, suatu daerah yang struktur masyarakatnya multietnis cenderung menggunakan satu bahasa (bahasa nasional) sebagai alat interaksi di antara para masyarakat yang berasal dari berbagai macam suku. Misalnya, di Lampung saat ada rapat tentang kepanitiaan upacara adat, dan rapat itu dihadiri oleh seorang pejabat, pada rapat itu tidak menggunakan bahasa daerah, tetapi bahasa Indonesia (Roveneldo, 2017). Penggunaan bahasa yang dapat berfungsi sebagai media komunikasi secara otomatis akan mengurangi tingkat penggunaan bahasa daerah masing-masing secara konstan.

Apa yang dibahas oleh Holmes (1989) tampaknya jelas bahwa pergeseran bahasa secara normal terjadi dalam kelompok bahasa minoritas yang berpindah ke tempat yang jauh dari tanah kelahirannya. Masyarakat ini cenderung sering menggunakan bahasa mereka dengan tujuan untuk menunjukkan identitas diri. Oleh karena itu, mereka juga lebih menyukai tinggal bersama secara berkelompok untuk memudahkan mereka untuk selalu bertemu dan juga mempertahankan bahasanya karena digunakan sehari-hari untuk berinteraksi satu sama lain.

Faktor lain yang memengaruhi pemertahanan bahasa adalah mobilitas atau frekuensi kunjungan ke tanah kelahiran atau ke daerah lain, baik yang lokasinya terdapat mayoritas suku mereka maupun yang minoritas bermukim di daerah tersebut. Arus imigran atau pengunjung baru secara tetap membutuhkan penggunaan bahasa yang terus berlanjut. Misalnya, imigran Polynesia dari Niue, Tokelau, dan Tonga tiba di New Zealand secara teratur. Orang Polinesia New Zealand memberikan keramahan kepada mereka dan pengunjung baru tentu saja memberikan input kebahasaan bagi masyarakat New Zealand. Prospek perjalanan tetap “mudik” ke tanah kelahiran memberikan motivasi yang sama untuk mempertahankan bahasa asalnya. Contohnya, orang Samoa 
di New Zealand selalu berharap untuk pulang ke daerah asalnya sebagai tanggung jawab terhadap keluarga. Imigran Yunani juga bepergian kembali ke Yunani sebagai prioritas utama bagi mereka dan anak-anaknya. Tindakan ini jelas menjadi alasan yang kuat untuk mempertahankan kemahiran dalam berbahasa Yunani (Holmes, 1989).

Holmes (1989) juga menambahkan faktor lain, yaitu dukungan institusi yang memberikan perbedaan antara sukses dan gagal dalam mempertahankan kelompok bahasa minoritas. Pendidikan, hukum, administrasi, agama, dan media adalah ranah yang penting yang berkenaan dengan masalah ini. Kelompok minoritas yang memberdayakan institusi ini untuk mendukung berhasilnya upaya untuk pemertahanan bahasa. Jika pemerintah suatu negara bertekad untuk menyelamatkan atau memelihara bahasa daerah, perlu memberikan peluang untuk melegalisasikan penggunaan bahasa daerah dalam semua ranah tersebut.

Berbeda dengan apa yang diungkapkan oleh (Romaine, 1989) yang menyebutkan sikap sebagai salah satu faktor yang berpengaruh dalam pergeseran bahasa secara terpisah. Dia menyatakan bahwa status bahasa yang berfungsi secara international dapat berkontribusi memberikan sikap positif seperti yang terjadi pada orang-orang Perancis di Kanada dan Amerika Serikat. Hal ini disebabkan karena bahasa Prancis memiliki status yang tinggi secara internasional. Contoh orang Prancis Amerika di Maine yang menganggap bahasa Prancis adalah bahasa yang baik untuk diketahui karena memiliki prestise internasional. Imigran Yunani merasa bangga bisa berkontribusi pada pemertahanan bahasa Yunani pada filsafat dan budaya Barat. Kesadaran ini penting bagi bahasa mereka untuk menolak peralihan bahasa ke bahasa Inggris.

Holmes (1989) menyatakan bahwa sikap memegang peranan yang penting dalam pemertahanan bahasa. Sebaliknya, Romaine (1989) menyebutkan bahwa identifikasi pada bahasa dan sikap positif terhadap bahasa tidak menjamin bahasa tersebut dapat bertahan. Dia memberikan bukti untuk mendukung pendapatnya sebagaimana yang dia temukan di Irlandia bahwa perlunya menggunakan bahasa Inggris yang telah mengalahkan antipasti terhadap bahasa Inggris dan penuturnya. Adopsi bahasa Inggris oleh orang Irlandia adalah kasus pergeseran bahasa yang tidak disertai sikap baik terhadap bahasa Irlandia (Macnamara, 1973). Perbedaan pendapat yang diungkapkan oleh kedua ahli tersebut tergantung dari masyarakat tempat penelitian 
mereka berlangsung. Tumbuhnya sikap positif terhadap penggunaan bahasa bisa saja dipengaruhi oleh status bahasa itu sendiri di dunia. Di samping itu, latar belakang sejarah yang mendukung orang Prancis sangat menjunjung tinggi bahasanya sehingga mereka selalu menggunakan bahasa Prancis ketika mereka berkunjung ke negara lain.

\section{METODE PENELITIAN}

Kuala Tanjung merupakan daerah industri yang sangat besar di Provinsi Sumatra Utara, yaitu dengan adanya proyek peleburan aluminium, yaitu PT Inalum. Proyek ini adalah proyek patungan antara Indonesia dan Jepang yang dimulai semenjak tanggal 6 Januari 1976. Pada awalnya daerah ini hanya ada PT Inalum itu saja, tetapi belakangan telah bertambah beberapa proyek industri yang berskala internasional, seperti pabrik pengelolaan minyak kelapa sawit, pelabuhan internasional, pembangunan sarana kereta api, dan berbagai industri terus tumbuh di wilayah ini. Pelabuhan Kuala Tanjung menjadi pelabuhan terbesar dan menjadi hubungan internasional di kawasan barat Indonesia. Pembangunan pelabuhan ini bertahap sampai dengan tahun 2023 dan nantinya akan memiliki kapasitas hingga mencapai 20 juta Teus. Akibat adanya industri yang berskala internasional tersebut, tingkat kehadiran masyarakat luar sangat tinggi, baik itu dari suku bangsa yang di Indonesia maupun dari luar negeri, khususnya Jepang.

Penelitian ini bersifat campuran, yaitu deskriptif kuantitatif-kualitatif yang dilaksanakan di wilayah Kuala Tanjung. Populasi yang digunakan adalah seluruh masyarakat yang berusia 6--12 tahun dan orang tua yang berusia 30--50 tahun yang merupakan warga asli di sekitar Kuala Tanjung yang menetap di tiga kecamatan di Kabupaten Batu Bara. Menurut data BPS Kabupaten Batu Bara tahun 2016, jumlah penduduk dari 3 kecamatan tersebut sebanyak 159.504 jiwa dari 404.988 jiwa penduduk Kabupaten Batu Bara. Sampel diambil dengan menggunakan multi stage sampling, yaitu dipilih 20 orang dari 3 kecamatan yang ada sehingga total sampel yang terpilih sebanyak 120 orang dengan perincian 60 orang sampel usia anak-anak dan 60 orang sampel usia orang tua. Data penelitian diperoleh melalui observasi, angket, dan wawancara yang sebelumnya telah diuji validitas dan reliabilitasnya. 


\section{PEMBAHASAN}

\section{Sikap Berbahasa}

Sikap sebagai salah satu faktor yang sangat berpengaruh, baik pada pemertahanan maupun pergeseran bahasa. Banyak penelitian yang berkenaan dengan fenomena bahasa tersebut menyimpulkan bahwa sikap berpengaruh signifikan terhadap pemertahanan bahasa karena sikap berkaitan erat dengan simbol identitas diri atau etnis suatu kelompok masyarakat. Ketika sekelompok masyarakat sangat menjunjung tinggi rasa kesukuannya, mereka cenderung menggunakan bahasa daerahnya sebagai simbol identitas diri. Begitu pula yang terjadi pada masyarakat Kuala Tanjung, sikap mereka terhadap bahasa daerah sangat positif. Hal ini sesuai dengan teori yang diajukan oleh Holmes (1989) yang menyatakan bahwa suatu bahasa dianggap menjadi simbol identitas etnis sehingga pada umumnya akan bertahan lebih lama. Dukungan sikap positif untuk terus berusaha menggunakan bahasa minoritas di berbagai ranah akan membantu orang menghindari tekanan dari kelompok mayoritas mengalihkan bahasa mereka. Berdasarkan hasil perhitungan, persentase data menunjukkan bahwa sikap orang tua berpengaruh terhadap pergeseran bahasa daerah di kalangan anak-anak di Kuala Tanjung. Hasilnya menunjukkan sikap positif responden terhadap penggunaan bahasa daerah, tetapi tidak memengaruhi keinginan mereka menggunakan bahasa tersebut ketika berkomunikasi dalam ranah keluarga dan di lembaga pendidikan.

Tabel 1

Pengetahuan tentang Bahasa Daerah

\begin{tabular}{clcccc}
\hline \multirow{2}{*}{ No. } & \multirow{2}{*}{ Pengetahuan tentang Bahasa Daerah (Aspek Kognitif) } & \multicolumn{2}{c}{ Orang tua } & \multicolumn{2}{c}{ Anak-anak } \\
\cline { 3 - 6 } & & $\mathbf{F}$ & $\mathbf{\%}$ & $\mathbf{F}$ & $\mathbf{\%}$ \\
\hline 1. & BD menunjukkan jati diri/identitas kedaerahan seseorang. & 229 & $95 \%$ & 222 & $93 \%$ \\
\hline 2. & $\begin{array}{l}\text { BD merupakan sarana komunikasi antarindividu, keluarga, } \\
\text { dan masyarakat di daerah. }\end{array}$ & 216 & $90 \%$ & 197 & $82 \%$ \\
\hline 3. & $\begin{array}{l}\text { BD menjadi sarana pendukung pengembangan kebudayaan } \\
\text { daerah di Indonesia. }\end{array}$ & 205 & $85 \%$ & 191 & $80 \%$ \\
\hline 4. & BD sebagai bahasa pengantar dalam pendidikan dasar. & 198 & $83 \%$ & 122 & $51 \%$ \\
\hline 5. & BD harus dilestarikan melalui program pemerintah daerah. & 238 & $99 \%$ & 218 & $91 \%$ \\
\hline
\end{tabular}

Tabel ini berkaitan dengan pernyataan yang berhubungan dengan pengetahuan, pemahaman, atau keyakinan terhadap fungsi dan manfaat bahasa daerah. Di sini terlihat bahwa kedua kelompok responden memiliki sikap yang positif terhadap bahasa daerahnya. Walaupun untuk pernyataan sebagai pengantar dalam pendidikan dasar, 
responden anak-anak jauh persentasenya dengan pernyataan yang lainnya. Mereka justru lebih senang menggunakan bahasa Indonesia.

Tabel 2

Penilaian terhadap Bahasa Daerah

\begin{tabular}{clcccc}
\hline \multirow{2}{*}{ No. } & \multirow{2}{*}{ Penilaian terhadap Bahasa Daerah (Aspek Afektif) } & \multicolumn{2}{c}{ Orang tua } & \multicolumn{2}{c}{ Anak-anak } \\
\cline { 3 - 6 } & & $\mathbf{F}$ & $\mathbf{\%}$ & $\mathbf{F}$ & $\mathbf{\%}$ \\
\hline 1. & $\begin{array}{l}\text { BD lebih bermartabat dibandingkan dengan BI dan bahasa } \\
\text { asing. }\end{array}$ & 186 & $78 \%$ & 133 & $55 \%$ \\
\hline 2. & Dengan menguasai BD membuat harga diri saya terangkat. & 172 & $72 \%$ & 131 & $55 \%$ \\
\hline 3. & Saya bangga dapat berbahasa daerah dengan baik. & 196 & $82 \%$ & 140 & $58 \%$ \\
\hline 4. & $\begin{array}{l}\text { Saya lebih mudah menyerap informasi yang disampaikan } \\
\text { dalam BD. }\end{array}$ & 207 & $86 \%$ & 136 & $57 \%$ \\
\hline 5. & Kosakata BD lebih mudah dipelajari daripada BI dan BA. & 214 & $89 \%$ & 153 & $64 \%$ \\
\hline
\end{tabular}

Pada pernyataan yang berhubungan dengan penilaian terlihat bahwa kedua kelompok responden agak berbeda penilaiannya. Pada responden orang tua justru secara signifikan positif terhadap bahasa daerahnya. Akan tetapi, pada responden anak-anak terlihat ada kesimbangan dalam penilaian sikap bahasa mereka.

Tabel 3

Kecenderungan terhadap Bahasa Daerah

\begin{tabular}{clcccc}
\hline \multirow{2}{*}{ No. } & \multicolumn{1}{c}{ Kecenderungan terhadap Bahasa Daerah (Aspek } & \multicolumn{2}{c}{ Orang tua } & \multicolumn{2}{c}{ Anak-anak } \\
\cline { 3 - 5 } Konatif) & \multicolumn{1}{c}{ F } & $\mathbf{\%}$ & F & $\mathbf{\%}$ \\
\hline 1. & Saya lebih sering menggunakan BD dalam berkomunikasi. & 217 & $90 \%$ & 108 & $45 \%$ \\
\hline 2. & $\begin{array}{l}\text { Saya lebih suka membaca buku-buku yang disajikan dalam } \\
\text { BD. }\end{array}$ & 151 & $63 \%$ & 120 & $50 \%$ \\
\hline 3. & $\begin{array}{l}\text { Saya lebih memilih menggunakan BD saat menyapa orang } \\
\text { asing walaupun tahu bahwa ia dapat BI. }\end{array}$ & 146 & $61 \%$ & 121 & $50 \%$ \\
\hline 4. & $\begin{array}{l}\text { Saya senang membantu orang lain yang mengalami } \\
\text { kesulitan dalam memahami BD. }\end{array}$ & 235 & $98 \%$ & 138 & $58 \%$ \\
\hline 5. & $\begin{array}{l}\text { Saya terbiasa menggunakan BD saat berinteraksi di media } \\
\text { sosial. }\end{array}$ & 180 & $75 \%$ & 125 & $52 \%$ \\
\hline
\end{tabular}

Bagian ini berisi pernyataan yang berhubungan dengan kecenderungan terhadap bahasa daerah. Pada responden orang tua terlihat lebih cenderung bersikap positif terhadap bahasa daerahnya. Berbeda dengan responden anak-anak justru tidak bersikap positif terhadap bahasa daerahnya.

Sikap positif mereka tidak mendukung penggunaan bahasa daerah dalam keluarga. Sebaliknya, mereka lebih banyak menggunakan bahasa Indonesia ketika bercakap-cakap dengan anak-anaknya. Fakta ini ditunjukkan oleh data kuesioner, hampir semua jawaban mereka mendukung penggunaan bahasa daerah dalam 
pendidikan, sosial, agama, dan budaya meskipun pada kenyataannya mereka jarang menggunakan bahasanya. Faktor lain yang menyebabkan kondisi tersebut adalah karena mereka dituntut untuk menggunakan bahasa Indonesia sebagai bahasa untuk berinteraksi dengan berbagai etnis yang menetap di Kuala Tanjung.

Adapun alasan mereka menggunakan bahasa Indonesia kepada anak-anaknya karena dianggap lebih mudah memberi pengertian jika menggunakan bahasa Indonesia karena anak-anak sudah terbiasa dengan bahasa itu. Apalagi dalam pergaulan atau bermain dan belajar dengan kawan-kawannya, mereka memang menggunakan bahasa Indonesia, walau ada sedikit dialek daerah yang digabung dalam bahasa itu. Selanjutnya, orang tua juga menunjukkan sikap positif terhadap penggunaan bahasa daerah. Sebagaimana terlihat pada Tabel 4 berikut yang merupakan hasil dari angket dalam skala Likert.

Tabel 4

Descriptif Statistik

\begin{tabular}{lccccc}
\hline & N & Minimum & Maksimum & Mean & $\begin{array}{c}\text { Standard } \\
\text { Deviasi }\end{array}$ \\
\hline SS & 60 & 15 & 60 & 43,55 & 15,323 \\
STS & 60 & 0 & 19 & 6,28 & 6,747 \\
Valid N (listwise) & 60 & & & & \\
\hline
\end{tabular}

Berdasarkan angka statistik di atas, terlihat bahwa dari 15 pertanyaan yang dijawab oleh 60 responden orang tua, ternyata responden menunjukkan sikap sangat positif dalam menanggapi penggunaan bahasa daerah.

Hasil penelitian ini relevan dengan penelitian yang dilakukan oleh Tom (2003), dia menguji pemertahanan bahasa Slovania di Carinthia (Austria). Dia menguji tiga parameter, seperti penggunaan bahasa, kompetensi bahasa, dan sikap bahasa. Dia juga menguji hasil tambahan yang diperoleh dari kelompok usia yang berbeda. Hasilnya menunjukkan bahwa jika suatu bahasa dapat bertahan, penutur yang muda pasti memiliki sikap yang layak terhadap bahasanya sebagaimana sikap orang yang lebih tua. Responden yang lebih muda juga menunjukkan sikap positif terhadap penggunaan bahasa Slovania di gereja. Dalam segala hal, mereka lebih bersikap positif dengan hal yang berkenaan dengan harapan untuk identitas dan masa depan bahasa Slovania. Akan tetapi, penelitian ini menunjukkan bahwa sikap positif yang ditunjukkan oleh orang tua di Kuala Tanjung tidak memberi kontribusi pada pemertahanan bahasa daerah. Sebaliknya, kondisi bahasa ini sedang mengalami fase bergeser di kalangan anak-anak. 
Sementara itu, berdasarkan lingkup sosiolinguistik makro, indikator pemertahanan bahasa dapat dilihat dari kelompok usia penutur bahasa yang masih menggunakan bahasa yang dimaksud (Mesthrie, 2000). Jika suatu bahasa masih bisa dituturkan oleh kelompok usia kanak-kanak, dapat dikatakan bahwa bahasa tersebut masih bertahan. Sebaliknya, jika penutur bahasa adalah kelompok lanjut usia, bahasa itu bisa dikategorikan bergeser. Hasil penelitian ini didukung oleh (Romaine, 1989) yang menemukan bahwa identifikasi pada bahasa dan sikap positif tidak menjamin pemertahanan bahasa tersebut seperti kasus bahasa Inggris yang terjadi di Irlandia.

\section{Pengaruh Orang Tua}

Berdasarkan temuan yang diperoleh dari data kuesioner dan hasil perhitungan persentase, dapat dinyatakan bahwa peran orangtua memberikan pengaruh terhadap pergeseran bahasa daerah di kalangan anak-anak. Ini berarti tingkat penggunaan bahasa yang dipraktikkan oleh orang tua ketika mereka berkomunikasi kepada anak-anak mereka secara tidak langsung memengaruhi penguasaan bahasa ibu oleh anak-anak tersebut. Ketika anak-anak terbiasa mendengarkan orang-orang yang ada dalam lingkungan mereka menggunakan bahasa ibu sejak dini atau dalam masa pemerolehan bahasa mereka, tentu saja hal ini membentuk kemampuan pemerolehan bahasa pertama pada mereka, baik secara aktif maupun pasif. Fenomena ini dapat dilihat pada Tabel 5 yang memperlihatkan penggunaan bahasa di ranah keluarga dalam lingkungan rumah tangga oleh anak-anak.

Tabel 5

Penggunaan Bahasa di Rumah

\begin{tabular}{cccc}
\hline No. & Bahasa & $\mathbf{F}$ & $\mathbf{\%}$ \\
\hline 1 & Bahasa Daerah & 119 & $13 \%$ \\
\hline 2 & Bahasa Indonesia & 781 & $87 \%$ \\
\hline 3 & Bahasa Asing & 0 & $0 \%$ \\
\hline & Jumlah & 900 & $100 \%$ \\
\hline
\end{tabular}

Berdasarkan tabel di atas, terlihat sangat signifikan, yaitu 87\% mereka menggunakan bahasa Indonesia di lingkungan keluarga. Pertanyaannya mengapa mereka lebih memilih menggunakan bahasa Indonesia? Jawabannya adalah karena dalam berkomunikasi di lingkungan keluarga itu dilayani oleh para orang tua mereka dengan bahasa Indonesia. Kenyataan ini akhirnya berdampak pada penggunaan bahasa di lingkungan masyarakat, di antaranya di sekolah mereka. Pada ranah situasi resmi dan 
tidak resmi di sekolah anak-anak lebih dominan menggunakan bahasa Indonesia daripada bahasa daerahnya. Untuk lebih jelasnya dapat dilihat pada tabel berikut ini.

Tabel 6

Penggunaan Bahasa di Sekolah Situasi Resmi (Soal 5)

\begin{tabular}{clcc}
\hline No. & Bahasa & F & \% \\
\hline 1 & Bahasa Daerah & 5 & $2 \%$ \\
\hline 2 & Bahasa Indonesia & 295 & $98 \%$ \\
\hline 3 & Bahasa Asing & 0 & $0 \%$ \\
\hline & Jumlah & 300 & $100 \%$ \\
\hline
\end{tabular}

Tabel 7

Penggunaan Bahasa di Sekolah Situasi Tidak Resmi (Soal 8)

\begin{tabular}{clcc}
\hline No. & Bahasa & F & \% \\
\hline 1 & Bahasa Daerah & 2 & $0,42 \%$ \\
\hline 2 & Bahasa Indonesia & 478 & $99,58 \%$ \\
\hline 3 & Bahasa Asing & 0 & $0 \%$ \\
\hline & Jumlah & 480 & $100 \%$ \\
\hline
\end{tabular}

Dua tabel terakhir menunjukkan sesuatu yang sangat signifikan penggunaan bahasa mereka. Bahkan, secara persentase justru lebih tinggi lagi persentase penggunaan bahasa Indonesia di sekolah dalam situasi tidak resmi dibanding pada situasi resmi. Di sini terlihat bahwa ada kecederungan bahwa anak-anak sudah meninggalkan bahasa daerahnya. Dengan demikian, sudah terjadi pergeseran bahasa di wilayah Kuala Tanjung ini. Akan tetapi, sangat disayangkan bahwa orang tua yang bermukim di Kuala Tanjung, lebih sering menggunakan bahasa Indonesia ketika berinteraksi kepada anak-anaknya. Bahkan, mereka juga lebih banyak menggunakan bahasa tersebut ketika berkomunikasi dengan orang lain. Hal ini disebabkan karena kondisi masyarakat di Kuala Tanjung yang multietnis. Oleh karena itu, kondisi inilah yang menjadi penyebab mengapa masyarakat Kuala Tanjung lebih memilih menggunakan bahasa Indonesia sebagai alat untuk berkomunikasi sehari-hari.

Sementara itu, responden orang tua yang setuju menggunakan bahasa daerah di rumah dengan anak-anaknya dan dengan orang Kuala Tanjung lainnya cenderung berpendapat sama bahwa mereka merasa lebih akrab atau rasa kekeluargaan lebih kental jika menggunakan bahasa daerah mereka. Berdasarkan data dari hasil wawancara yang menjelaskan bahwa penggunaan bahasa daerah oleh orang tua kepada anak-anaknya sangat memengaruhi kemampuan berbahasa daerah mereka. Selanjutnya, hal ini secara tidak langsung berpengaruh pada pergeseran bahasa daerah di Kuala Tanjung. 
Hasil penelitian ini didukung oleh teori yang diajukan oleh Sun (2000) dalam penelitian tentang pemertahanan bahasa pada keluarga imigran Cina, di mana peran orang dalam mempertahankan bahasanya sangat signifikan. Hasil penelitian ini juga sejalan dengan hasil yang ditemukan oleh Tannenbaum \& Pauline Howie (2002) di mana keluarga memegang peran penting dalam mempertahankan anak-anak Cina lebih menggunakan bahasa ibu orang tua mereka. Sementara itu, Benjamin (1993) juga menemukan pentingnya peran keluarga dalam mempertahankan bahasa Spanyol pada anak-anak Meksiko. Sama halnya dengan apa yang ditemukan oleh Bodnitski (2007), dia juga menyimpulkan bahwa faktor yang sangat penting dalam mempertahankan bahasa pertama adalah penggunaan bahasa minoritas dalam kehidupan sehari-hari.

\section{PENUTUP}

Berdasarkan penelitian yang telah dilakukan terlihat bahwa penggunaan bahasa daerah oleh orang tua dalam ranah keluarga dapat berpegaruh pada pergeseran serta pemertahanan bahasa daerah yang umumnya terjadi di kalangan anak-anak meskipun bahasa daerah tersebut dituturkan di daerah asalnya sendiri. Hal ini dibuktikan oleh hasil analisis kuesioner, yaitu hampir semua jawaban responden menyatakan tidak menggunakan bahasa daerah dalam berkomunikasi dengan keluarga, handai taulan, dan orang lain. Ini berarti peran orang tua memberikan pengaruh pada pergeseran bahasa yang dialami anak-anak di Kuala Tanjung.

Sikap orang tua terhadap bahasa daerah masih cukup positif berdasarkan data kuesioner dengan menggunakan analisis persentase. Akan tetapi, sikap ini tidak memberikan konstribusi pada pemertahanan bahasa daerah di Kuala Tanjung itu sendiri. Hal ini dikarenakan faktor interaksi yang menyebabkan mereka dituntut untuk menggunakan bahasa Indonesia sebagai bahasa untuk berinteraksi dengan berbagai etnis yang menetap di Kuala Tanjung. Data menunjukkan anak-anak di Kuala Tanjung jarang menggunakan bahasa daerah, bahkan ada beberapa responden yang tidak memahami bahasa tersebut baik secara aktif maupun pasif.

Sesuai dengan hasil penelitian, disarankan kepada setiap orang tua haruslah mengajarkan bahasa daerahnya kepada anak-anak mereka. Dengan demikian, keberadaan bahasa daerah itu akan tetap bertahan karena telah diwariskan kepada generasi berikutnya. 


\section{DAFTAR PUSTAKA}

Adisaputera, A. (2009). Potensi Kepunahan Bahasa pada Komunitas Melayu Langkat di Stabat, Kabupaten Langkat, Sumatera Utara. Dalam Logat Jurnal Ilmiah Bahasa dan Sastra, 1, 45-55.

Benjamin, R. (1993). The Maintenance of Spanish by Mexicano Children and Its Function in Their School Lives. California.

Berutu, L. (2016). Perkembangan Penduduk serta Pengaruhnya terhadap Pergeseran Budaya Pakpak dalam Sistem Bahasa, dan Organisasi Sosial di Dairi. Universitas Medan.

Bodnitski, J. (2007). First Language Maintenance or Loss: Ukrainian Immigrant Families' Perspectives. Canada: York University.

Chaer, A., \& Leonie Agustina. (2004). Sosiolinguistik: Perkenalan Awal. Jakarta: PT. Rineka Cipta.

Chang, M. (1996). Language Use and Language Attitudes Among Taiwanese Elementary School Students in Native Language Instruction Programs: A Study on Language Maintenance, Language Shift, and Language Planning in Taiwan. Indiana: Indiana University.

Dorian, N. (1981). Language Death: the Life Cycle of a Scottish Gaelic Dialect. Philadelphia: University of Pennsylvania Press.

Fasold, R. (1984). The Sociolinguistics of Society. England: Basic Blackwell, Inc.

Fishman, J. (1964). Language Maintenance and Language Shift as Fields of Inquiry. Dalam Linguistics, 9, 32-70.

Fishman, J. A. (1980). Bilingualism and Biculturism as Individual and as Societal Phenomena. Dalam Journal of Multilingual and Multicultural Development, 1.

Fishman, J. A. (1990). What is Reversing Language Shift (RLS) and How Can it Succeed? Dalam Journal of Multilingual and Multicultural Development Volume, 11.

Fishman, J. A. (2012). Language Maintenance, Language Shift, and Reversing Language Shift. In The Handbook of Bilingualism and Multilingualism. Second Edition.

Fishman, J. A. \& Others. (1966). Language Loyalty in the United States: The Maintenance and Perpetuation of Non-English Mother Tongues by American Ethnic and Religious Groups. Dalam ERIC Number: ED036217, Record Type: RIE, Publication.

Gafaranga, J. (2010). Medium Request: Talking Language Shift into being. Language in Society, 39 (2), 241-270.

Gal, S. (1979). Language Shift: Social Determinants of Linguistic Change in Bilingual Austria. New York: Academic Press.

Hickey, R. (2010). Contact and Language Shift. In Handbook of Language Contact.

Holmes, J. (1989). Bilingualism. USA: Blackwell Publisher Ltd.

Hornberger, N. H., \& King, K. A. (2011). Reversing Quechua Language Shift in South America. Can Threatened Languages be Saved?: Reversing Language Shift, Revisited: a 21st Century Perspective.

Jumharia, D. (2015). Influential Factors in The Maintenance of Tamil Language Among Indian Societies in Medan, North Sumatera”. Makalah International Seminar "Language Maintenance and Shift. V ISSN, 2088 (6799), 2-3.

Kandler, A., Unger, R., \& Steele, J. (2010). Language Shift, Bilingualism and the Future of Britain's Celtic Languages. Philosophical Transactions of the Royal 
Society B: Biological Sciences, 365 (1559), 3855-3864.

Kloss, H. (1966). German-American Language Maintenance Efforts. In J. Fishman (Ed.). The Hague: Mouton.

Kramsch. (1998). Language and Culture. London: Cambridge University Press.

Küün, E. (2015). Impact of Change of the Language Environment on the Extent of Language Shift in the Context of Linguistics. Journal Trames, 19 (1), 73-91.

Lyons, J. (1970). Introduction to Theoretical Linguistics. London: Cambriedge University Press.

Macnamara, J. (1973). Nurseries, Streets and Classrooms: Some Comparisons and Deductions. Dalam The Modern Language Journal.

Mesthrie, R. (2000). Introducing Sociolinguistics. Edinburgh: Edinburgh University Press.

Moriguchi-McCormick, Y. (1999). The Relationship Between Attitudes Toward FirstLanguage Maintenance and First-Language Literacy Skills Among Japanese Children Sojourning in the San Francisco Bay Area. California: University of San Fransisco.

Musgrave, S. (2014). Language Shift and Language Maintenance in Indonesia. Language, Education and Nation-Building, 87-105.

Myers-Scotton, C. (2013). Paradigm Shift in Language Planning and Policy: GameTheoretic Solutions. Journal Language Policy, 12, 383-385.

Ozerk, K. \& Jon. T. (2013). Written Language Shift among Norwegian Youth. International Electronic Journal of Elementary Education, 5 (3), 285-300.

Posel, D. dan Z., \& Jochen. (2016). Language Shift or Increased Bilingualism in South Africa: Evidence from Census Data. Journal of Multilingual and Multicultural Development, 37 (4), 357-370.

Prochazka, K. \& Gero V. (2017). Quantifying the Driving Factors for Language Shift in a Bilingual Region. In Proceedings of the National Academy of Sciences (Vol. 114, p. 4369).

Rina, T. (2017). Pemertahanan Bahasa Batak dalam Ikatan Mahasiswa Sumatera Utara (Kajian Sosiolinguistik). Medan: USU.

Romaine, S. (1989). Bilingualism. Massavhusetts: Blackwell Publisher Ltd.

Roveneldo. (2017). Prosesi Perkawinan Lampung Pepadun: Sebagai Bentuk Pelestarian Bahasa Lampung. Ranah: Jurnal Kajian Bahasa, 6 (2), 220-234. https://doi.org.10.26499/rnhv6i2.265

Sembiring, A. W. (2015). Pergeseran dan Pemertahanan Bahasa di dalam Perkawinan Campuran: Sebuah Studi Kasus dalam Keluarga Suku Karo. Tesis. Medan: Unimed.

Smith-Christmas, C. (2014). Being Socialised into Language Shift: the Impact of Extended Family Members on Family Language Policy. Journal of Multilingual and Multicultural Development, 35 (5), 511-526.

Sun, L. (2000). First Language Maintenance in Recent Chinese Immigrant Families. Texas: Texas Tech University.

Tannenbaum, M. \& Pauline Howie. (2002). The Association between Language Maintenance and Family Relations: Chinese Immigrant Children in Australia. Journal of Multilingual and Multicultural Development, 23 (5), 408-424.

Tom, P. (2003). Maintenance of Slovene in Carinthia (Austria): Grounds for Guarded Optimism? Canadian Slavonic Papers, 45 (1/2), 95-117.

Tse, L. (2001). Resisting and Reversing Language Shift: Heritage-Language Resilience 
among U.S. Native Biliterates. Harvard Educational Review, 71 (4), 676-709.

Wardaugh. (2002). Sociolinguistics. Great Britain. Cambridge: Cambridge University Press.

Yagmur, K., Bot, K. De, \& Korzilius, H. (1999). Language Attrition, Language Shift and Ethnolinguistic Vitality of Turkish in Australia. Dalam Journal of Multilingual and Multicultural Development. Vol. 20, p. 51--69. 